\title{
Serbia Robotics Hall of Fame: the Impact of the Past
}

\author{
Branko Karan \\ Institute of Technical Sciences of the Serbian Academy of Sciences and Arts, Belgrade, Serbia \\ branko.karaneitn.sanu.ac.rs
}

\begin{abstract}
The paper presents a list of the most influential works of Serbian robotics. The list has been synthesized using document citation data from the Elsevier Scopus database and it shows that the impact of Serbia, compared to neighboring countries, has been highly disproportional and outperforming having in mind the Serbian economic and general scientific strength. However, the analysis also reveals that Serbia's contribution has been significantly weakened during the last ten years and that Serbian robotics has been declining with respect to neighboring countries.
\end{abstract}

Keywords: Serbian robotics $\cdot$ scientific impact $\cdot$ robotics papers

\section{Introduction}

Scientific strength of a nation has many dimensions. It can be expressed in a number of researchers, number of produced scientific articles, patents, defended dissertations, etc. Yet, it is commonly agreed that the main attribute reflecting the scientific merit is the number of citations in works published in refereed journals, conference proceedings, and other renowned sources. Here, the highly cited works are of special importance. Having in mind that distribution of citations has a characteristic skewed shape, with a relatively small number of high-impact documents, and large numbers of documents of minimal impact, the key measure of scientific performance is a capability of producing or supporting highly cited works [1].

Using a scientific metrics, G. Mester recently presented a list of top scientists in robotics in Serbia based on citations in Google Scholar [2]. Here, a slightly different goal has been posed, that is to identify the top impact works originating from the research institutions of Serbia - and to highlight research fields in which these top results have been achieved. At the same time, a comparison between Serbia and neighboring countries has been made in order to determine relative differences in contribution as well as to emphasize possible issues in scientific production.

\section{Methodology Remarks}

At the first glance, once it has been agreed that the number of citations is an appropriate measure of impact, the task of finding the most influential works of national robotics could seem straightforward. Yet, there are few subtle details that deserve more 
attention. Here, the issues are elaborated that are connected to the actual measurement of the influence, country of origin, and the field of the influence.

\subsection{Number of Citations}

For many practical reasons, determining the number of citations is performed by modern standards using data from publicly available citation indexing services. Today, citation indexing databases that are most commonly used in scientific community are Thomson Reuters Science Citation Index (SCI), Elsevier Scopus, and Google Scholar, all providing online retrieval features. This analysis was conducted using only Scopus data. The reason to choose Scopus rather than SCI was trivial: in the Serbian academy network, there was no access to SCI records for years prior 1996.

Clearly, different citations may have different importance, depending e.g. on the context of citation or the impact of the journal or other source in which the citing work has been published. Yet, for practical reasons, the citations were in this work simply counted, albeit being aware of limited value of such a simplification. The counts were calculated without self-citations because only the proper citations could serve as a measure of influence; at best, a large number of self-citations may signal the self-influence or a constancy and dedication to research subject.

When identifying the list of top cited works, only the works with 20 or more citations have been considered. This number was arbitrary chosen in order to make the list compact - for a more advanced and influential research environment than Serbia, a limit of 50 or even 100 citations could be more suitable.

Data in Scopus database are divided in two groups: primary sources, for which the lists of references are retrieved and indexed by Scopus, and secondary sources, which may appear in Scopus only as referenced documents. In this work, when investigating the database, both primary and secondary sources were considered, because references to both kinds of sources were properly indexed by Scopus.

\subsection{Country of Origin}

Information on affiliation of authors is available for each document appearing in Scopus database and this information was used to determine the country of origin of the published work. In case of a document with several affiliations, only the first enlisted affiliation was regarded as relevant, because it normally identifies an organization or institution in which the research was organized or conducted.

\subsection{Importance to Robotics Community}

Robotics is by its nature an interdisciplinary field of research, combining knowledge from many diverse disciplines. It is hard to find any scientific field without some influence to robotics, from operations research to psychology and from material engineering to ergonomy. The border between robotics and other relevant fields is often fuzzy and a question of whether a research belongs to robotics is, to a great extent, a matter of personal taste. 
However, while it is extremely difficult to filter-out "truly" robotic papers in efficient and bias-free manner, the task of determining papers with significant influence in robotics is much easier. Namely, we can easily adopt as the most influencing those papers that have received the greatest attention in renowned robotic journals.

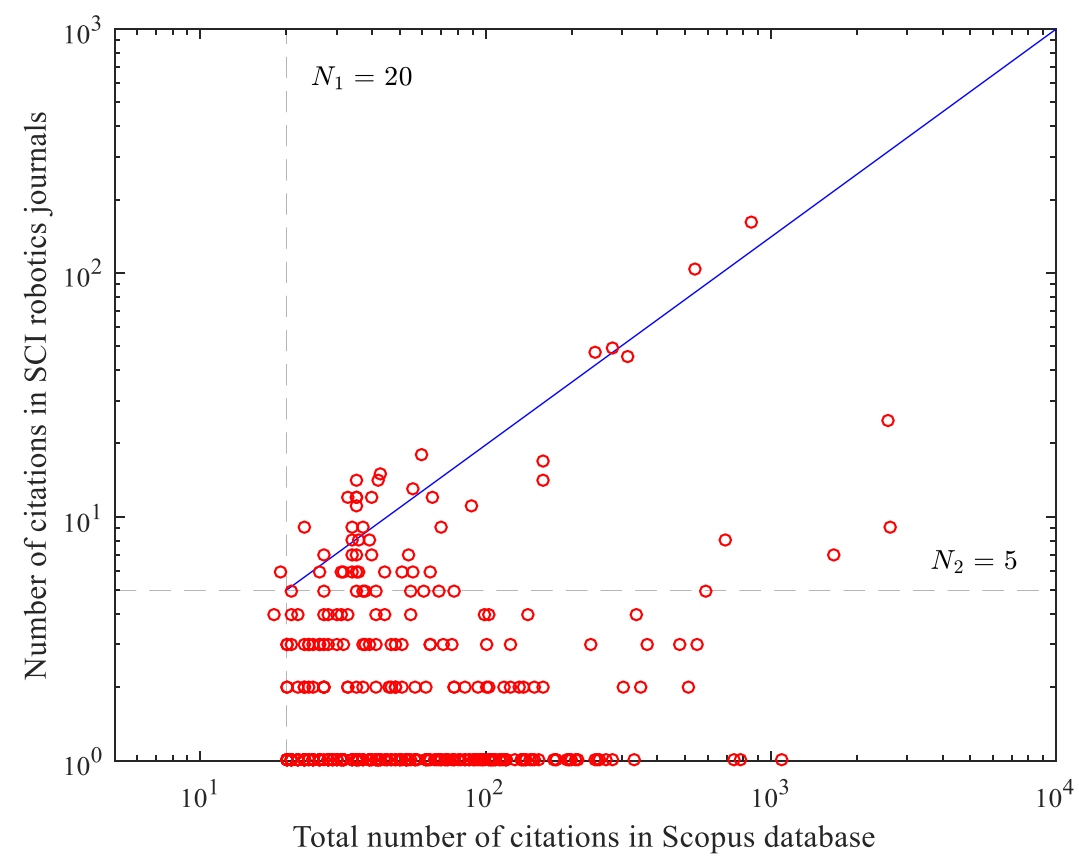

Fig. 1. Citation data for a sample of 344 highly cited works referenced in SCI robotics journals

In this work, the list of high-impact robotic journals provided by Thomson Reuters (SCIROB hereafter) was used for this purpose. Still, the question remained on the number of citations in SCIROB journals that signaled the high influence. To answer it, a diagram for a sample of high-cited journals was prepared (see Fig. 1). The diagram shows clear clustering of highly cited works in two parts: the works that were only occasionally cited in SCIROB journals (those with 1-4 SCIROB citations) and the works for which there was a strong correlation between the total number of citations and citations in SCIROB journals, with a trend of having a portion of SCIROB citations ranging from about $25 \%$ for papers with 20 citations down to $10 \%$ for highly cited papers with 100 or more citations. Applying a linear function is a bit impractical, so for the purpose of this analysis a simpler criterion of minimum 5 citations in SCIROB is adopted as a signal of significant impact in robotics.

\section{The List of Most Influencing Works}

Following the described $20+5$ criterion, the list of the most cited robotics works was synthesized from Scopus database starting from all the documents cited by SCIROB 
journals (totally about 450,000 documents cited by some 25,000 SCIROB papers), then by extracting the subset with affiliation from Serbia/Yugoslavia, sorting afterward the extracted documents by the number of citations and finally by examining the documents with 20 or more citations: for each document, a check was made of whether the affiliation of the first author was an institution from Serbia, and for each such a document, the database was again queried for a total number of citations and the number of citations in SCIROB journals. The process resulted in a list of 17 Serbian works with 5 or more SCIROB citations. The list is presented in Table 1 which also contains, for each document, the number of citations in all journals indexed in Scopus.

What immediately catches the eye in Table 1 is the absolute prevalence of works of Miomir Vukobratović, who authored 13 out of 17 documents (and also coauthored 2 additional documents). The remaining 4 papers were authored by D. Katić [9], R. Tomović [10], M. Gavrilović [15] and B. Karan [16]. Aside from M. Vukobratović, the most successful in producing high-impact works were B. Borovac and M. Kirćanski, each with 3 works, and Y. Stepanenko, D. Juričić, and V. Potkonjak, each with 2 works.

Manja Kirćanski, who collaborated with Prof. Vukobratović in three highly cited works on trajectory generation for manipulation robots [11], [14], [18], rightfully deserves the title of the first lady of the Serbian robotics.

It is interesting to note that all the documents from the list were produced at the institutions from the University of Belgrade: Mihajlo Pupin Institute and the School of Electrical Engineering. For 16 out of 17 works, affiliation of the first author was Mihajlo Pupin Institute, the house of famous "Belgrade school of robotics" headed and promoted by M. Vukobratović, a longtime director of its Robotics Centre. The only exception was the paper by R. Tomović et al. [10] that was made while the author was with the School of Electrical Engineering.

There is no room here for a detailed analysis of subjects of these works. However, few comments can be made. All the works mainly belong to the so called classical robotics, dealing with modeling and motion control of robotic and robotized mechanisms, including various complex active orthotic and prosthetic devices. The top impact, with more than 200 citations per document, is exhibited by the works on biped locomotion [3], [4], [5], [6], and [7]. Bipedal walk is also the main subject of several other top cited documents [8], [9], [12], and [13]. Besides two papers concerning active orthoses and prostheses [8], [15], focal points of all other papers are related to manipulation robots, including dynamic modeling [19], trajectory synthesis [11], [14], [18], contact tasks [17], grasping [10], and calibration and accuracy [16].

An issue that should concern today is the age of the works. The last work in Table 1 was published in 2006 and it is now already 10 years old. However, despite the old age, these works still have a large frequency of citation: notably, they received 195 citations in Scopus database only in the course of the last year; out of these, 101 were the citations of the top Vukobratović and Borovac paper [3]. 
Table 1. Serbian works with highest impact in robotics

\begin{tabular}{|c|c|c|c|c|c|}
\hline & Year & Document & 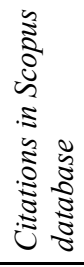 & 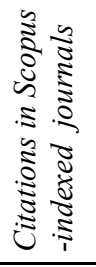 & 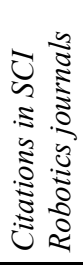 \\
\hline 1 & 2004 & $\begin{array}{l}\text { Vukobratović, M., Borovac, B.: Zero-moment point - } \\
\text { thirty five years of its life [3] }\end{array}$ & 860 & 348 & 163 \\
\hline 2 & 1990 & $\begin{array}{l}\text { Vukobratović, M., Borovac, B., Surla, D., Stokić, D.: } \\
\text { Biped locomotion: dynamics, stability, control, and } \\
\text { application [4] }\end{array}$ & 543 & 256 & 104 \\
\hline 3 & 1972 & $\begin{array}{l}\text { Vukobratović, M., Stepanenko, Y.: On the stability of } \\
\text { anthropomorphic systems [5] }\end{array}$ & 322 & 118 & 45 \\
\hline 4 & 1969 & $\begin{array}{l}\text { Vukobratović, M., Juričić, D.: Contribution to the synthe- } \\
\text { sis of biped gait [6] }\end{array}$ & 309 & 115 & 49 \\
\hline 5 & 1970 & $\begin{array}{l}\text { Vukobratović, M., Frank, .A., Juričić, D.: On the stability } \\
\text { of biped locomotion [7] }\end{array}$ & 243 & 114 & 47 \\
\hline 6 & 1974 & $\begin{array}{l}\text { Vukobratović, M., Hristić, D., Stojiljković, Z.: Develop- } \\
\text { ment of active anthropomorphic exoskeletons [8] }\end{array}$ & 90 & 47 & 11 \\
\hline 7 & 2003 & $\begin{array}{l}\text { Katić, D., Vukobratović, M.: Survey of intelligent control } \\
\text { techniques for humanoid robots [9] }\end{array}$ & 54 & 23 & 7 \\
\hline 8 & 1987 & $\begin{array}{l}\text { Tomović, R., Bekey, G., Karplus, W.J.: A strategy for } \\
\text { grasp synthesis with multifingered robot hands [10] }\end{array}$ & 51 & 40 & 15 \\
\hline 9 & 1984 & $\begin{array}{l}\text { Vukobratović, M., Kirćanski, M.: A dynamic approach to } \\
\text { nominal trajectory synthesis for redundant manip- } \\
\text { ulators [11] }\end{array}$ & 43 & 32 & 14 \\
\hline 10 & 2006 & $\begin{array}{l}\text { Vukobratović, M., Borovac, B., Potkonjak, V.: ZMP: A } \\
\text { review of some basic misunderstandings [12] }\end{array}$ & 40 & 23 & 12 \\
\hline 11 & 1973 & $\begin{array}{l}\text { Vukobratović, M., Stepanenko, Y.: Mathematical models } \\
\text { of general anthropomorphic systems [13] }\end{array}$ & 38 & 27 & 9 \\
\hline 12 & 1982 & $\begin{array}{l}\text { Vukobratović, M., Kirćanski, M.: Method for optimal syn- } \\
\text { thesis of manipulation robot trajectories [14] }\end{array}$ & 37 & 33 & 12 \\
\hline 13 & 1969 & $\begin{array}{l}\text { Gavrilović, M., Marić, M.: Positional servo-mechanism } \\
\text { activated by artificial muscles [15] }\end{array}$ & 36 & 20 & 8 \\
\hline 14 & 1994 & $\begin{array}{l}\text { Karan, B., Vukobratović, M.: Calibration and accuracy of } \\
\text { manipulation robot models - an Overview [16] }\end{array}$ & 34 & 24 & 9 \\
\hline 15 & 1999 & $\begin{array}{l}\text { Vukobratović, M., Potkonjak, V., Dynamics of contact } \\
\text { tasks in robotics. Part I: General model of robot } \\
\text { interacting with environment [17] }\end{array}$ & 34 & 20 & 5 \\
\hline 16 & 1986 & $\begin{array}{l}\text { Vukobratović, M., Kirćanski, M.: Kinematics and trajec- } \\
\text { tory synthesis of manipulation robots }[18]\end{array}$ & 29 & 23 & 9 \\
\hline 17 & 1985 & $\begin{array}{l}\text { Vukobratović, M., Kirćanski, N.: Real-time dynamics of } \\
\text { manipulation robots [19] }\end{array}$ & 28 & 23 & 6 \\
\hline
\end{tabular}


Related to the question of the age of works is the age of their authors. Currently, the only active roboticists in Serbia with their papers enlisted in the Table 1 are B. Borovac, V. Potkonjak and B. Karan, all well in the middle sixties. Here, it is worth noting that the last years witnessed strong expansion of robotic centers in Mihajlo Pupin Institute, Belgrade School of Electrical Engineering, and Faculty of Technical Sciences in Novi Sad. They have engaged talented young people, but their time is yet to come. They still do not have top achievements that would be possibly reflected in high impact.

\section{Comparison to Neighboring Countries}

To get a better insight into actual impact of Serbia robotics, a comparison was made to neighboring countries having the similar geographic position and more-or-less similar human and economic potentials (similar in the sense of being on the same order of magnitude). To this end, the process of extracting the articles with the top impact in robotics was repeated for all Serbian neighbors plus Slovenia (hereafter, the neighboring region), which has been traditionally seen in Serbia as a desired model of organization in many fields.

Importantly, this analysis has shown that the influence of the regional robotics should not be exaggerated: out of some 450,000 references found in SCIROB journals, only a bit less than 2,700 or $0.6 \%$ have been identified as the citations of the works from the region. However, out of these 2,700 references, almost $20 \%$ are citations to works from the Table 1.

The analysis resulted in extracting 57 highly cited papers from the region. Distribution of papers among countries is displayed in Figure 2, which shows that the countries with the largest number of high-impact robotic papers are Slovenia, Serbia, and Hungary, which together contribute to more than three-quarters of all papers. This result should be regarded as more than satisfactory, having in mind that technology research and development in Serbia has been regularly weakly funded. Compared to e.g. Slovenia, total expenditure for research and development in Serbia was about 3.4 (in 2010) to 4.6 (in 2000) times smaller [20].

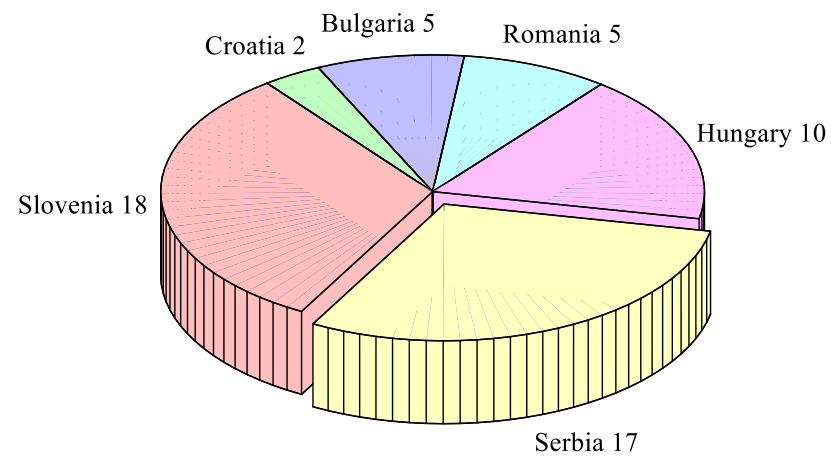

Fig. 2. Serbia share in highly cited robotic works from the region 

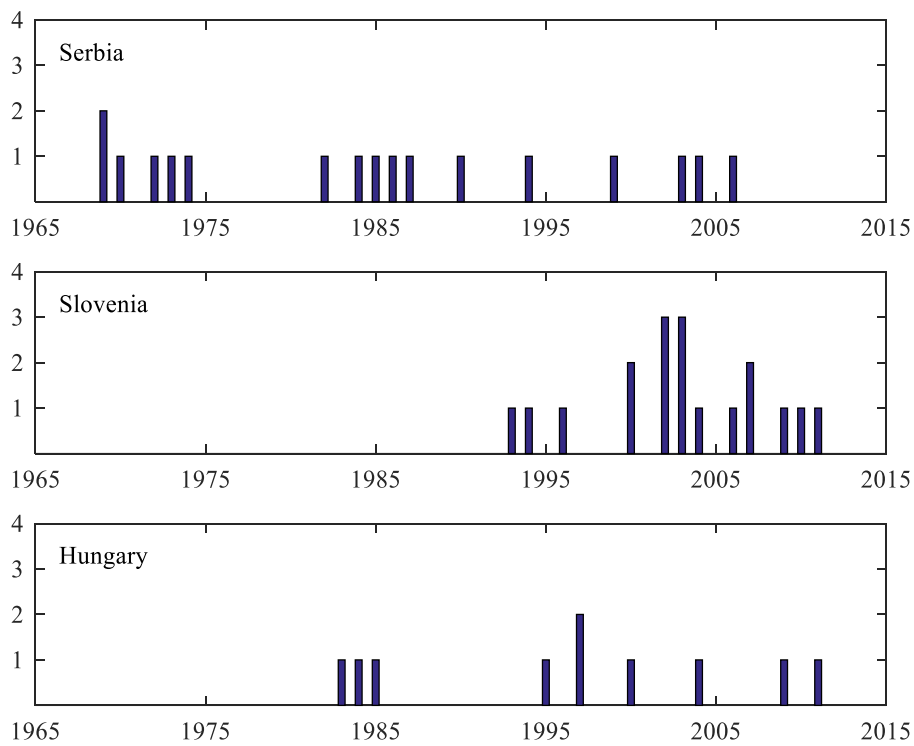

Fig. 3. Timeline of highly cited robotic works in Serbia and neighboring countries

However, the picture changes when considering the time of production of highimpact works. Figure 3, which displays the timeline of highly cited works for three leading countries from the region, evidently shows a decrease in frequency of publication from Serbia. Here, it is interesting to note that the majority of high-impact works from Slovenia and Hungary in the last ten years come from non-traditional robotic fields, such as high-level pattern recognition, control of mobile robots, learning by imitation, bioinspired vision, and fuzzy logic-based swarm coordination.

\section{$5 \quad$ Instead of Conclusion}

This paper repeats more-or-less known facts that robotics research in Serbia was for a long time concentrated in Belgrade Mihajlo Pupin Institute, thanks to enormous energy of Miomir Vukobratović to explore new horizons and to gather and motivate talented engineers. However, the list of top published works presented here offers details that might be new to many researchers.

To author's best knowledge, this is the first time that such a list has been published. It may have errors, both at methodological and technical levels. To provide a space for discussion and improvements, the page http://www.danuberobotics.org/srhf shall be established after the RAAD 2016 conference. The site shall also contain additional data that could not be presented here due to the limited space.

Acknowledgments This work was supported in part by the Serbian Ministry of Education, Science and Technology Development. Additional thanks are owed to Danube Robotics, LLC, for providing Internet resources for the online presentation. 


\section{References}

1. Narin, F., Hamilton, K.S.: Bibliometric performance measures. Scientometrics, 36(3), 293310 (1996).

2. Mester, G.: Indexes in scientific metrics - application in robotics (in Serbo-Croatian.) In: Proc. 2015 ETRAN Conference, Srebrno Jezero, Serbia (2015)

3. Vukobratović, M., Borovac, B.: Zero-Moment Point - Thirty Five Years of Its Life. International Journal of Humanoid Robotics 1(1), 157-173 (2004)

4. Vukobratović, M., Borovac, B., Surla, D., Stokić, D.: Biped Locomotion: Dynamics, Stability, Control, and Application. Communications and Control Engineering Series, vol. 7. Springer Berlin Heidelberg (1990)

5. Vukobratović, M., Stepanenko, Y.: On the Stability of Anthropomorphic Systems. Mathematical Biosciences 15(1) 1-37 (1972)

6. Vukobratović, M., Juričić, D: Contribution to the Synthesis of Biped Gait. IEEE Transactions on Biomedical Engineering 16(1), 1-69 (1969)

7. Vukobratović, M., Frank, A., Juričić, D.: On the Stability of Biped Locomotion. IEEE Transactions on Biomedical Engineering 17(1), 25-36 (1970)

8. Vukobratović, M., Hristić, D., Stojiljković, Z.: Development of Active Anthropomorphic Exoskeletons. Medical and Biological Engineering 12(1), 66-80 (1974)

9. Katić, D., Vukobratović, M.: Survey of Intelligent Control Techniques for Humanoid Robots. Journal of Intelligent and Robotic Systems 37(2), 117-141 (2003)

10. Tomović, R., Bekey, G., Karplus, W.J.: A Strategy for Grasp Synthesis with MultiFingered Robot Hands. In: Proc. 1987 IEEE International Conference on Robotics and Automation, vol. 4, 83-89. IEEE (1987)

11. Vukobratović, M., Kirćanski, M.: A Dynamic Approach to Nominal Trajectory Synthesis for Redundant Manipulators. IEEE Transactions on Systems, Man and Cybernetics 14(4), 580-586 (1984)

12. Vukobratović, M., Borovac, B., Potkonjak, V.: ZMP: A Review of Some Basic Misunderstandings. International Journal of Humanoid Robotics 3(2), 153-175 (2006)

13. Vukobratović, M., Stepanenko, Y.: Mathematical Models of General Anthropomorphic Systems. Mathematical Biosciences 17(3), 191-242 (1973)

14. Vukobratović, M., Kirćanski, M.: Method for Optimal Synthesis of Manipulation Robot Trajectories. Journal of Dynamic Systems, Measurement, and Control 104(2), 188-193 (1982)

15. Gavrilović, M., Marić, M.: Positional Servo-Mechanism Activated by Artificial Muscles. Medical and Biological Engineering 7(1), 77-82 (1969)

16. Karan, B., Vukobratović, M.: Calibration and Accuracy of Manipulation Robot Modelsan Overview. Mechanism and Machine Theory 29(3), 479-500 (1994)

17. Vukobratović, M., Potkonjak, V.: Dynamics of Contact Tasks in Robotics. Part I: General Model of Robot Interacting with Environment. Mechanism and Machine Theory 34(6), 923-942 (1999)

18. Vukobratović, M., Kirćanski, M.: Kinematics and Trajectory Synthesis of Manipulation Robots. Communications and Control Engineering Series, vol. 3. Springer Berlin Heidelberg (1986)

19. Vukobratović, M., Kirćanski, N.: Real-Time Dynamics of Manipulation Robots. Communications and Control Engineering Series, vol. 4. Springer Berlin Heidelberg (1985)

20. World Bank Data, http://data.worldbank.org/ 